\title{
Research on the Current Situation and Countermeasures of Cross-Border Electronic Commerce Law Supervision
}

\author{
Haolan Shi* \\ Northwest University of Political Science and Law, Xi'an 710122, China \\ *Corresponding Author's e-mail: letusdiealittle@gmail.com
}

\begin{abstract}
Economic development has been stimulated, and many urgent problems have also arisen, especially in legal supervision. The imperfect regulatory system has fundamentally affected the development of cross-border e-commerce. Therefore, from the perspective of legal supervision, this article analyzes the current problems and proposes solutions from the three aspects of supervision subject, supervision object and supervision content, aiming at how to create a more favorable environment for the development of cross-border e-commerce in China Provide reference and reference.
\end{abstract}

Keywords: Cross-border e-commerce, legal supervision, supervision content

\section{INTRODUCTION}

Since 2010, China's cross-border e-commerce has developed rapidly at a rate of more than $30 \%$ per year, forming a development pattern with exports as the mainstay and imports as a supplement, promoting a new direction for the transformation of China's import and export trade structure. The emergence of cross-border ecommerce has effectively simplified foreign trade business processes, changed the way of international trade supervision, and promoted the diversification of international trade business entities. As a new breakthrough in the traditional trade model, cross-border e-commerce has great potential that the world sees. After ten years of development, China's cross-border ecommerce has now entered a period of relatively flat but steady progress from a period of rapid development [1]. As an emerging industry and hot spot, cross-border ecommerce has all the content that a research object should contain. This article mainly studies and improves related issues from the legal level of the regulatory system of cross-border e-commerce supervision, and discusses how to improve China's cross-border ecommerce regulatory system from the level of transaction entities, payment, dispute resolution mechanisms, and the system formed by regulatory entities, and put forward some innovative suggestions in order to provide reference for solving the corresponding problems [2].

\section{THE MEANING OF CROSS-BORDER E- COMMERCE}

Cross-border e-commerce can be summarized as transaction entities belonging to different customs, using the Internet and other electronic communication methods to facilitate transactions (transaction inquiry, negotiation, conclusion of contracts, performance of contracts, etc.), and deliver them through cross-border logistics or remote storage. International business activities to reach products and complete transactions. In a broad sense, cross-border e-commerce can generally refer to a business model that uses e-commerce technology in any link of cross-border transactions [3].

E-commerce activities involving cross-border elements on domestic e-commerce platforms can be defined as cross-border e-commerce. E-commerce activities cover several aspects. Foreign legal persons or unincorporated organizations enter the platform to sell goods and services to the country. For example, many foreign companies engage in business activities on platforms such as Tmall and JD.com. Domestic legal persons or unincorporated organizations sell goods or services overseas on the platform. For example, many sellers sell and export goods to overseas buyers on One Access [4]. Both sellers and buyers on the platform are domestic enterprises, but the delivery of goods involves import and export situations. The transaction takes place in China, but the delivery of goods or the provision of 
services takes place overseas. The "New Deal for Crossborder E-commerce" that is currently hotly discussed in the business world actually only refers to the crossborder e-commerce retail industry that can achieve the "three orders" comparison of logistics, payment, and transaction electronic information through transactions on an e-commerce transaction platform connected to the customs [5].

\section{CURRENT PROBLEMS IN TRANSNATIONAL E-COMMERCE}

\subsection{Supervisory Authority is Intertwined}

At present, China has not yet established a special department to conduct unified supervision of crossborder e-commerce. Various ministries and commissions have issued a large number of administrative regulations on cross-border e-commerce issues, and they are all hoping to supervise this part of the content [6]. Therefore, when there is a problem with cross-border ecommerce, it is the situation in which the regulatory documents formulated by the involved ministries and commissions are in charge of the situation. Even the contents of regulatory documents formulated by relevant departments will overlap each other, resulting in a chaotic situation of intertwining powers and responsibilities among supervisory entities. This situation is not conducive to effective supervision of cross-border e-commerce. Too many departments involved will lead to complicated and delayed problem solving. In terms of inefficiency in the handling process, it will lead to adverse consequences that hinder its development in the long run [7].

\subsection{Lack of Guiding Law}

Cross-border e-commerce is developing rapidly in China, but it lacks corresponding laws and regulations. Cross-border e-commerce is a new type of trade, with various trading methods, which are also very different from traditional trade development. In terms of customs, commodity inspection, taxation, collection and payment, etc., due to the application of past cross-border ecommerce laws and regulations, it is difficult to comprehensively supervise these contents in a traditional way, leading to various chaotic problems. In China, sexual laws have attracted widespread market attention. The new "E-commerce Law" stipulates that cross-border e-commerce is only a principled regulation, and the standardization method is also relatively general. Although daigou, wechat and webcast are included in the scope of supervision, the current supervision of daigou by major platforms [8]. No specific rules have been issued yet, and many problems have arisen.

\subsection{Unclear Rights and Obligations of the Subject of Supervision}

Although China's cross-border e-commerce has developed on a considerable scale, it is still in its infancy in terms of time, and there is still a long way to go before it matures. Regarding the differentiation of transaction subjects and the refinement of categories, no regulatory document has been found to classify them in detail. Therefore, the subjects of cross-border e-commerce in China often hold several roles, sometimes they are intermediaries who provide intermediary services, and sometimes they operate their own products. They are often unable to distinguish their roles and distinguish their functions. It is dazzling and misty, which brings great difficulties to legislative work and supervision [9].

As mentioned above, the subject of supervision of cross-border e-commerce in China, that is, the transaction subject, is only roughly classified and summarized by some regulatory documents. The rights and obligations that should be fulfilled are due to the authorization of regulatory levels (such as instability, variability, etc.) cannot be implemented well one by one. At the same time, the classification of transaction entities in the regulatory documents is also different, which leads to the difficulty in identifying transaction entities and the application of corresponding regulatory documents when the regulatory entities perform their supervisory duties.

\subsection{Regulatory Issues for Third-party Platform Payments}

Regarding the legal documents related to ecommerce payment, from financial institutions to nonfinancial institutions, from the central bank to the Internet, it can be seen that financial security is related to national security, so the state should pay more attention to it. Therefore, the problem of payment supervision is mainly reflected in the rise of large-scale network service platforms such as Taobao, Tmall, and e Bay [10]. Consumers only need to place an order when shopping and transfer the money to a third-party platform for payment. When successful, the third-party platform will then pay the goods and service providers. Then, there is a regulatory problem. When the buyer sends the money to the third-party platform, who will ensure the safety of the money, and if the money is misappropriated for other purposes, who will protect the legitimate rights and interests of the buyer and the seller. 


\section{COUNTERMEASURES FOR PERFECTING CROSS-BORDER E- COMMERCE SUPERVISION}

\subsection{Improve the Supervision Mechanism of Transaction Subjects}

Since the government generally does not intervene in the development of cross-border e-commerce, and only regulates its absolutely impossible, this has led to few legislative documents for transaction subjects. Some new trading entities will often emerge. Due to the lack of corresponding legislative and regulatory documents, the regulatory entities are often unable to start and unsustainable. In order to effectively solve the complexity and variability of transaction subjects, the author believes that a systematic supervision model can be constructed from three aspects: platform supervision, industry self-discipline and government supervision.

First of all, it is platform supervision. The department responsible for supervision will promote the establishment of a special platform for cross-border ecommerce. This platform will be used as a transaction portal for cross-border e-commerce in China and has certain permissions. Under the guidance of the platform's operating specifications, all enterprises should conduct true and effective registration for management in accordance with the classification categories established by the platform. At the same time, the platform should also formulate cross-border ecommerce transaction guidelines and regulations within the scope of the principles and rules of civil law and commercial law to regulate various transaction activities of transaction subjects. The platform should also establish a systematic and complete reward and punishment mechanism. On the one hand, it can mobilize the enthusiasm of transaction subjects, and on the other hand, it can promptly remove the black sheep and ensure the health and purity of cross-border e-commerce transaction subjects.

Secondly, government supervision is mainly divided into two levels. The first is to establish a supervisory mechanism that combines pre- and post-supervision, that is, to conduct a thorough review of the qualifications and credit systems of cross-border e-commerce transaction entities beforehand, strictly control entry gates, and prohibit companies that do not meet the standards. Participate in cross-border e-commerce transaction activities. Subsequent supervision is mainly reflected in the promotion of the establishment of a cross-border ecommerce transaction information data system. Each transaction data of the transaction subject in cross-border e-commerce activities should be reported to the system to facilitate the government functional departments to pursue accountability after the event. Second, to promote the formulation of corresponding regulatory documents, the government should conduct more research work on cross-border e-commerce, and accurately grasp the constraints and regulatory loopholes it faces in the development process, so as to formulate corresponding regulatory documents in a timely manner to solve them and supervision to escort the development of crossborder e-commerce.

\subsection{Improve the E-commerce Legal System}

E-commerce Law clearly stipulates: "For goods or services related to the lives and health of consumers, the e-commerce platform operators have not fully reviewed the qualifications of the operators on the platform. If the obligation to the consumer is not fulfilled, and the consumer is harmed, he shall bear the corresponding responsibility in accordance with the law. The management department shall order corrections within a time limit, and may impose a fine of 50,000 yuan to 500,000 yuan; if the circumstances are serious, it shall be ordered to suspend business for rectification and impose a fine of 500,000 yuan to 2 million yuan." Starting from the legal system of border e-commerce, the relevant legal system is taken as an important guarantee. This is also the foundation to ensure the development of cross-border e-commerce. Constructing a reasonable legal system is the main direction of future development. In terms of customs clearance efficiency, import and export management departments should promote the realization of information sharing and regulatory mutual recognition among relevant regulatory agencies for cross-border ecommerce. This will help save customs clearance time, improve customs clearance efficiency, and promote trade facilitation. However, the links of declaration, tax payment, inspection and quarantine still need to be further improved.

Some small wholesale goods require relatively high customs clearance efficiency, and there is currently a lack of a more complete customs clearance plan. In the relevant bill, the import and export management department should promote the construction of a single window, realize the comprehensive development and mutual supervision of cross-border e-commerce, and improve the convenience of declaration and trade. Strengthen the determination of related infringement liability of third parties and further establish brand awareness. In addition, the 14 provisions on issues related to electronic invoices shall be properly used.

\subsection{Build a Credit Supervision Mechanism Based on Payment}

In terms of payment system, China has constructed a relatively comprehensive supervision system from laws and regulations to local government regulations. After all, financial security is an important part of national security. Virtual payment behaviors relying on the 
Internet as a medium are derived. Although China has also issued relevant regulations to guide and supervise Internet payment behavior, there are still areas where there are no regulatory documents that can be supervised. For example, the use and safety of funds under the thirdparty platform payment system has not yet formulated laws and regulations to supervise it. Therefore, in view of this loophole, the author believes that the leakage should be blocked from the legislative level.

Based on thinking about the Zhima credit mechanism under Alipay, the author believes that a mechanism similar to Zhima credit can be established in the payment system of cross-border e-commerce. This kind of credit mechanism closely connects the subject of cross-border e-commerce transactions with the subject of consumption, and relies on the establishment of a credit evaluation system to divide credit levels. Different levels can enjoy certain rights, such as taxation policies, customs clearance procedures, and import and export. Priorities in logistics. The establishment of a special subject authorized by the legislation is responsible for constructing the corresponding information evaluation system and credit rating system, and requires all subjects participating in cross-border e-commerce transaction activities to register at the portal provided by the subject, if it is an individual. You should provide valid identification information that you can inquire about. If you are an enterprise, you should provide a valid business license number to ensure the accuracy, reliability and safety of credit evaluation. At the same time, the credit rating is linked to each transaction data of the transaction entity. The special entity can establish specific quantitative scoring indicators by drawing on the international standards established by the international credit system, and delimit different levels a range for systematic and standardized supervision.

\subsection{Clarify the Power and Responsibility Boundaries Between Supervisory Entities}

There are many regulatory entities involved in crossborder e-commerce. As long as they have the right to formulate regulatory documents, they have the power to supervise cross-border e-commerce. Then it is inevitable that there will be overlapping regulatory powers and responsibilities, which will lead to multiple management and repeated enforcement. This is contrary to China's policy on the development of cross-border e-commerce. The government hopes to give cross-border e-commerce Development creates a relatively free environment so that it can develop steadily and rapidly under the guidance of market operating rules. However, if each department wants to expand its power and intervene in the development of cross-border e-commerce, it may cause market failure and hinder the development of cross-border e-commerce.
In terms of the subjects with supervisory powers and responsibilities for cross-border e-commerce. They enjoy certain regulatory authority over cross-border ecommerce. Among them, the General Office of the State Council, the Ministry of Finance, and the National Development and Reform Commission are mainly responsible for drafting support policies for cross-border e-commerce and macro guidance for the development of cross-border e-commerce; the Ministry of Commerce is mainly responsible for defining the concepts and models of e-commerce and regulating e-commerce transactions; the State Administration for Industry and Commerce has stipulated the rights and obligations of e-commerce transaction subjects and explained consumer rights protection channels; the General Post Office is mainly responsible for the supervision of the logistics part of cross-border e-commerce; the State Administration of Taxation supervises e-commerce taxation issues, such as determining tax types, tax rates, and preferential tax policies; the General Administration of Customs is mainly aimed at the clearance of customs clearance procedures for cross-border e-commerce products, the registration and filing of transaction activities undertaken by transaction entities, and the tax collection and management of a small number of goods; the People's Bank of China and the China Banking Regulatory Commission mainly supervise payment behaviors in cross-border trade. All departments should take the initiative to clarify the division of powers and responsibilities, and conduct special supervision on cross-border e-commerce related content within their own functional scope instead of multiple supervision and joint law enforcement. In areas where functions overlap, relevant departments can try to establish a mutual cooperation mechanism, which not only facilitates the supervision of cross-border e-commerce, but also clarifies the ownership of rights and responsibilities between departments, first to facilitate self-relief of transaction subjects, and second, to facilitate interdepartmental Undertake internal responsibilities and avoid prevarication.

\section{CONCLUSION}

China's cross-border e-commerce legal supervision system is still in its infancy, and it is seriously incompatible with the development speed of China's cross-border e-commerce. With the integration of global trade and the increasing proportion of cross-border ecommerce in international trade, China should raise cross-border e-commerce to the legal level and regulate it, aiming to provide a way for its healthy and robust development. The suggestions put forward in the article hope to have some reference and reference for the construction of the legal supervision system of crossborder e-commerce. We should pay attention to the supervision of various contents of cross-border ecommerce, promote the development of cross-border e- 
commerce, better protect the rights and interests of consumers, actively apply electronic signatures, and explore more protection mechanisms.

\section{REFERENCES}

[1] W.Q. Wang. Research on China's Cross-border Ecommerce Retail Import Tax Issues and Countermeasures. Northern Economics and Trade, 2020, vol.12, pp.33-35.

[2] L. Huang. Study on the development status and countermeasures of cross-border e-commerce. Today's Fortune (China Intellectual Property), 2020, vol.12, pp.52-53.

[3] F.L. Chen. Research on the Impact of Sino-US Trade Frictions on Chinese Cross-border E-commerce Enterprises and Countermeasures. China Business Journal, 2020, vol.4, pp.101-102.

[4] T.T. Jin. Research on Taxation of Cross-border Ecommerce in China. Journal of Shaanxi Vocational and Technical College, 2019, vol.14, pp.47-49+52.

[5] X.Y. Feng, Y. Xun. Analysis of the status quo of China's cross-border e-commerce development. China Collective Economy, 2019, vol.11, pp.86-87.

[6] Bi Yating. Research on International Settlement Methods under the Background of Cross-border Ecommerce. Mall Modernization, 2019, vol.5, pp.6869.

[7] C.J. Xiong. Analysis of the impact of RMB internationalization on cross-border e-commerce. Financial Economics, 2019, vol.4, pp.24-25.

[8] B. Zhang, H. Lv. Research on the Impact of Ecommerce Carnival on Cross-border E-commerce Export. Shanxi Youth, 2017, vol.21, pp.59-60.

[9] X.F. Tang. The status quo and countermeasures of legal supervision of cross-border e-commerce in China. Journal of Wuyi University(Social Science Edition), 2017, vol.19, pp.65-68+94.

[10] Y. Wang. Study on the status quo of China's crossborder e-commerce and legal regulations. Times Finance, 2017, vol.6, pp.227. 